\title{
The Relationship of Illustrated Health Warnings on Cigarette Packaging to Quitting Intentions of Pamulang University Students
}

\author{
Gaung Eka Ramadhan \\ Sekolah Tinggi Ilmu Kesehatan Pertamedika, Jakarta Selatan, DKI Jakarta, Indonesia \\ *e-mail: gaungekaramadhan@gmail.com
}

\begin{abstract}
This study analyzes the relationship between pictorial health warnings on cigarette packaging and the intention to quit smoking for Pamulang University students. This research design uses quantitative analysis with a cross-sectional method complemented by qualitative respondents, namely Pamulang University students totaling 100 respondents. This research was conducted from December 2019 - January 2020. The data analysis used univariate analysis, bivariate analysis, and multivariate analysis. The results showed that there was a significant relationship between perceptions of pictorial health messages and the intention to stop smoking, the p-value indicated this: 0.000 and the OR value 43.5; there is a significant relationship between knowledge and intention to stop smoking with a p-value: 0.000 and $O R$ value 75.6;
\end{abstract}

Keywords: pictorial health messages, intention to quit smoking

Article Information

Received: May 07, 2021; Revised: May 26, 2021; Online: June 01, 2021

\section{INTRODUCTION}

Smoking behavior has become a common addictive behavior. Smoking behavior is the act of someone doing smoking activities or actions intended to simulate smoking, and the results of a person's decision have considered the pros and cons of smoking (Efendi: 2005). Information about cigarettes from the environment is an important thing that influences whether smoking is good or not. Therefore, the decisionmaking process to smoke is strongly influenced by the environment.

Various scientific studies have proven that smoking is one of the main risk factors for heart disease, cancer, chronic lung disease, mouth, and throat cancer and can be fatal to cause death. We can even find smoking behavior in younger age groups, namely school students, and even smoking is partly carried out in the school environment. Smoking turns out not only to cause several deadly medical hazards, but cigarettes also have psychological dangers, such as depression and schizophrenia (Albery \& Mufano: 2011). Smoking addiction is also a form of addictive behavior that becomes a mental health problem, grouped into addiction disorders.

There are several stages in smoking behavior; there are four stages in smoking, namely the preparation stage (preparatory), the initiation stage (initiation), the stage of becoming a smoker (becoming a smoker), and the stage of permanent smoking (maintaining of smoking). In the preparation stage, a person is interested and intends to smoke, while in the pioneering stage, someone tries and decides to continue smoking; at the smoking stage, a person has consumed more regularly up to 4 cigarettes per day, while at the permanent smoker stage someone has been addicted to the pleasant effects of cigarettes and does not can stop (Elizabeth: 2010). Smoking habits begin 
with the first cigarette; several studies have found that the first cigarette begins at 11-13 years. Smoking behavior is caused by curiosity and peer influence.

Smoking behavior is the behavior of sucking tobacco rolls wrapped in palm leaves or paper. Smoking is a habit that can pleasure the smoker and hurt both the smoker himself and his environment. Cigarettes have a bad impact on health because cigarettes contain 4000 harmful chemicals that can damage health. However, cigarette consumption remains high and becomes an addictive problem that is difficult to break the chain. Even smoking behavior is started by teenagers (Jaya: 2009). Quitting smoking is a radical behavior change. The intention is the main predictor of behavior. The intention to stop smoking is a determinant of smoking cessation success in the younger generation (Akmal et al.:, 2017). Beginner smokers are those who are very young, namely teenagers. This behavior begins in adolescence and increases to become a regular smoker within a few years (Tulenan et al., 2015). There are many reasons behind smoking behavior in adolescents, apart from environmental factors. Smoking behavior is initiated by curiosity and peer influence (Komalasi, 2012; Tulenan et al., 2015).

The number of active smokers continues to grow in Indonesia so that Indonesia is ranked 4th with the highest number of active smokers and tobacco consumers in the world after China, Russia, and America in 2009. The number of cigarettes consumed reached 260.8 billion. This number increased from 2007 when Indonesia only consumed 239 billion cigarettes (Tobacco Altas: 2012). The Global Youth Tobacco Survey (GYTS) in 2006, the prevalence of Indonesian adolescents who smoked was $12.6 \%$, wherein males, and it was $24.5 \%$ higher than females $2.3 \%$ (GYTS, 2006). At the same time, the results of the Global Youth Tobacco Survey (GYTS) in 2009 surveyed adolescents aged 13-15 years, as many as 20.3 adolescents were found to have smoking behavior $(41 \%$ were male and $3.5 \%$ were female) (GYTS, 2009).

One of the government's efforts to reduce cigarette consumption and protect the public from exposure to cigarette smoke is by issuing Government Regulation of the Republic of
Indonesia Number 109 of 2012 concerning the Safety of Materials Containing Addictive Substances in the Form of Tobacco Products for Health. The Government Regulation of the Republic of Indonesia Article 27, number 109 of 2012 explains that tobacco packaging and advertisements must include a warning image. Explicit messages must consist of $40 \%$ of the front and back area of the cigarette pack.

To support this regulation, the Minister of Health in 2013 issued Minister of Health Regulation No. 28 of 2013, concerning the Inclusion of Health Warnings and Health Information on Tobacco Product Packaging. In this regulation, it is required for all cigarette companies to include Health Warnings in the form of images on cigarette packaging; there are five health image messages suggested in this regulation. In Indonesia, this regulation was only implemented in June 2014. The purpose of warning images on cigarette packaging is to reduce cigarette consumption and the desire to quit smoking, especially in adolescents reaching adulthood. Based data from Riskesdas shows an increase in the prevalence of smoking in 2013, which was $7.2 \%$ to $9.1 \%$ in 2018 .

According to Ajzen and Fishbein (2005), the intention to quit smoking is also influenced by three factors, namely individual attitudes towards certain behaviors, subjective norms, namely social norms that affect individuals, and behavioral control, which is defined as individual perceptions of their ability to exercise self-control to act or not. The smoking intention is a person's intention to burn, smoke, hold a cigarette based on motivational factors, attitudes, social norms, self-control, and beliefs to display behavior. In other words, smoking is an individual's intention to bring up or not bring up the behavior.

According to Notoatmodjo in Heryanto et al. (2017), knowledge or cognition is important for forming one's actions. From experience and research, it turns out that behavior based on knowledge will be more absorbent than behavior that is not based on knowledge before people adopt a new behavior (behaving in a new person in a sequential process), awareness, feeling interested, considering, trial, adaptation. Heryanto et al.'s (2017) research show that respondents who know health warning images prefer light smokers. If accepting a new 
behavior or adopting a behavior goes through a process like this, based on knowledge, awareness, and a positive attitude, then the behavior will be long-lasting. On the other hand, if the behavior is not based on knowledge and awareness, it will not last long. So, the importance of knowledge here is that it can be the basis for changing behavior to last.

Managanta and Hudaya (2018) state that the low awareness of pictorial messages can also be seen from the public's lack of concern for pictorial warnings on cigarette packs, which can be seen from the public's freedom to smoke in public places or near children, both other people's children and their children. Awareness of the dangers of smoking in the form of continuously carried out images is expected to bring changes in smokers' behavior until they stop smoking. Pictorial warnings on cigarette packs are expected to convey negative messages and change the behavior of smokers and even stop smoking. Furthermore, Managanta and Hudaya (2018) state that family and friends are related to the intention to quit smoking; the better the family support for smoking cessation obtained by smokers, the higher the tendency to have the intention to stop smoking, based on this, the better the family environment of the smoker, the higher the tendency to have the intention to quit smoking, the family environment has a very large contribution to the intention to quit smoke. A person's positive attitude towards health may not automatically impact a person's behavior, but a negative attitude towards health almost certainly can hurt his behavior. Negative attitudes about smoking can still change if individuals get input, experience, or positive environmental behavior that does not support smoking behavior.

The subjects in this study were Pamulang University students who were part of late adolescence, expected to have better health knowledge and behavior than other adolescents who did not receive higher education, Pamulang University students who were generally teenagers, or those who were generally teenagers who were approaching adulthood. (late adolescence) With an age range between 18-24 years, there are three stages of adolescent development in the process of adjustment to adulthood. Early adolescents between the ages of 12-15 years, middle or middle adolescents between the ages of 15-18 years, and late adolescence between 18-24 years.

This stage of middle adolescence requires friends and narcissistic tendencies. In addition, at this stage, adolescents are also in a state of confusion because they do not know which one to choose: sensitive or indifferent: crowd or alone, idealistic or materialist, and so on. Teenage boys must free themselves from the Oedipus complex by strengthening relationships with friends of the opposite sex (Aswin, 2017). Adolescents are usually socially-minded, gregarious, and like groups. Thus the peer group has a self-evaluation and adolescent behavior. In order to gain group acceptance, early adolescents seek to conform fully to matters such as dress style, hairstyle, taste in music, and grammar, often sacrificing individuality and self-determination.

\section{Illustrated Health Warning}

The World Health Organization (WHO) Framework Convention On Tobacco (FCTC) is the first international health treaty to make new regulations for tobacco control laws (WHO, 2003). The purpose of the FCTC agreement is to reduce the supply and demand for tobacco products in countries that are parties to this agreement. One of the main principles in the FCTC is that "everyone has the right to get clear information about the harmful effects on health due to addiction from tobacco consumption (Hammond David: 2012).

According to WHO, the FCTC discussion results are that cigarette manufacturers are required to use images of the effects of cigarettes and include them on cigarette packs. It is used to communicate to smokers about the health risks that occur if they continue to smoke. The FCTC requires a warning label in an image to accompany the writing on the warning label found on cigarette packs. The image attached must be at least $30 \%$ on the cigarette pack; this special warning must be conspicuous and must be on every pack of cigarettes. Each country with different versions regulates these regulatory policies, and cigarette packs must provide information on the product ingredients' composition.

Indonesia itself became the 5th country in ASEAN to implement Pictorial Health Warnings, Implementation of Health Warning 
policies in the form of Images in Cigarette Packs in Indonesia after Singapore, Thailand, Brunei Darussalam, Malaysia, and the 3rd country in SEARO (Regional WHO Southeast Asia) after Thailand and India.

In Government Regulation (P.P.) No. 109 of 2012 concerning the Safeguarding of Materials Containing Addictive Substances in Tobacco Products for Health regarding cigarette packaging and labeling provisions. Some things are explained that:

a) Each cigarette variant is required to include a picture and a health warning letter consisting of five different images, each with a percentage of $20 \%$ (twenty percent) of the number of each cigarette variant.

b) The inclusion of health warning images and writings must be on the top of the packaging, front and back surfaces with an area of $40 \%$ (forty percent) each.

c) Information on nicotine and tar content must be clear and placed on the side of the cigarette package.

d) On the other side of cigarette packs, the statement "it is forbidden to sell or give to children under 18 years of age and pregnant women".

In the Regulation of the Minister of Health of the Republic of Indonesia Number 28 of 2013, the Illustrated Health Warnings listed on cigarette packaging consist of five images with five different messages, namely:

a) Oral cancer image with the message "Smoking Causes Oral Cancer."

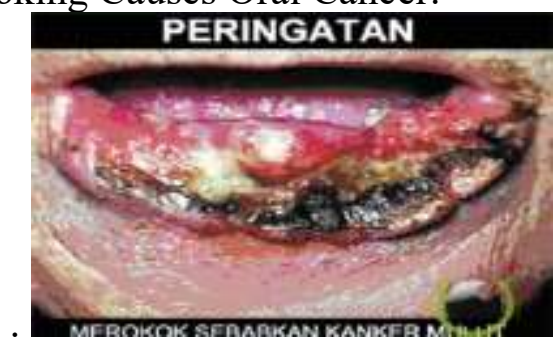

Figure .1 Oral Cancer

b) Image of a smoking person with smoke forming a skull with the message "Smoking is Killing You."

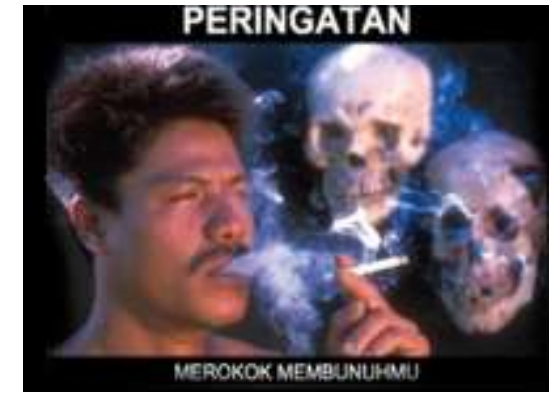

Figure 2. People smoking with smoke resembling a skull

c) An image of a blackened lung due to cancer with the message "Smoking Causes Lung Cancer and Chronic Bronchitis."

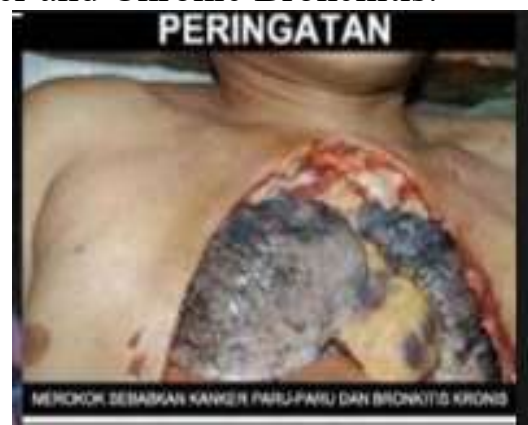

Figure 3. Lung Cancer

d) Throat cancer image with the message "Smoking Causes Throat Cancer."

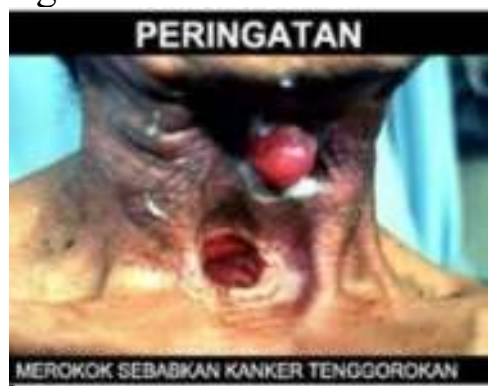

Figure 4. Throat Cancer

e) Image of a person smoking with a child nearby with the message "Smoking Near Children is Dangerous for Them."

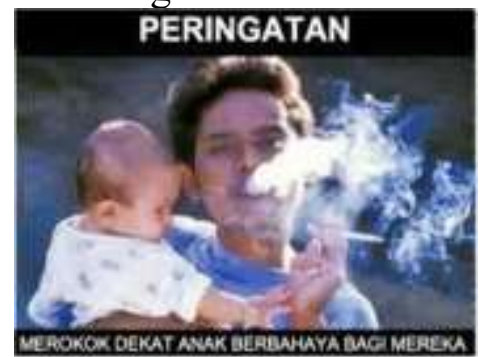

Figure 5. People smoking with small children

The five picture messages were selected based on the research results conducted by the University of Indonesia Health Research Center 
(2007) in Cirebon and Jakarta. Illustrated Health Warning content must contain different issues related to tobacco use in addition to the adverse health effects, such as recommendations to quit,

\section{METHODS}

The research was carried out quantitatively, complemented by qualitative ones. The research design used was cross-sectional, where data on the dependent or dependent variables and independent or independent variables would be collected simultaneously, temporary in nature, and each subject was only observed once. The main purpose of this research is to make a description or description of a situation objectively.

The population in this study were male Pamulang University students, namely 29,819 students, but from the total population, researchers did not have data on the number of active smokers in that population. Based on the sample calculation, the researcher believes with the addictive nature of tobacco, the social and economic harm it causes, and the significant impact of using tobacco products on others.

a 95\% confidence level that the random sample size is 96.04 . Seeing these results, the researcher rounded the number of samples to 100 people to facilitate the data calculation.

The method of collecting data in this study was by interviewing questionnaires to Pamulang University students who smoked. The researcher explained and gave instructions first, then supervised while the students filled out the questionnaire, and after the questionnaire was completed, it was immediately handed back to the researcher. Data analysis was carried out to support analytical activities to prove the hypothesis, the analytical techniques used in this study were univariate analysis, bivariate analysis, multivariate analysis.

\section{RESULTS}

Table 1. The relationship between the perception of Figure 1 and the intention to stop smoking

\begin{tabular}{|c|c|c|c|c|c|c|c|c|}
\hline \multirow{3}{*}{$\begin{array}{c}\text { Image } \\
\text { Perception } \\
1\end{array}$} & \multicolumn{4}{|c|}{ Intention to Quit Smoking } & \multirow{2}{*}{\multicolumn{2}{|c|}{ Total }} & \multirow{3}{*}{$\begin{array}{c}\text { OR } \\
(95 \% \\
\text { CI) }\end{array}$} & \multirow{3}{*}{ P-value } \\
\hline & & ow & 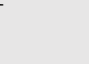 & all & & & & \\
\hline & $\mathbf{F}$ & $\%$ & $\mathbf{F}$ & $\%$ & $\mathbf{F}$ & $\%$ & & \\
\hline Not & 11 & $73.3 \%$ & 4 & $26.7 \%$ & 15 & $100 \%$ & \multirow{4}{*}{0.267} & \multirow{4}{*}{0.000} \\
\hline Protective & & & & & & & & \\
\hline Protective & 0 & $0 \%$ & 85 & $100 \%$ & 85 & $100 \%$ & & \\
\hline Total & 11 & $11 \%$ & 89 & $89 \%$ & 100 & $100 \%$ & & \\
\hline
\end{tabular}

Table 1 shows that the relationship between respondents' perceptions of Figure 1 and the intention to stop smoking obtained a value of $p=0.000(p<0.05)$, which means a significant relationship between Figure 1 and the intention to stop smoking. From the analysis results, the value of $\mathrm{OR}=0.267$, which means that respondents who have an effective perception of Figure 1 have a 0.26 times chance of influencing the high intention to stop smoking compared to ineffective images.

Table 2. The relationship between perceptions of Figure 2

\begin{tabular}{|c|c|c|c|c|c|c|c|c|}
\hline \multirow{3}{*}{$\begin{array}{c}\text { Image } \\
\text { Perception } \\
2\end{array}$} & \multicolumn{4}{|c|}{ Intention to Quit Smoking } & \multirow{2}{*}{\multicolumn{2}{|c|}{ Total }} & \multirow{3}{*}{$\begin{array}{c}\text { OR } \\
(95 \% \\
\text { CI }) \\
\end{array}$} & \multirow{3}{*}{ P-value } \\
\hline & \multicolumn{2}{|c|}{ Low } & \multicolumn{2}{|c|}{ Tall } & & & & \\
\hline & $\mathbf{F}$ & $\%$ & $\mathbf{F}$ & $\%$ & $\mathbf{F}$ & $\%$ & & \\
\hline Not & 10 & $43.5 \%$ & 13 & $56.5 \%$ & 23 & $100 \%$ & & \\
\hline Protective & & & & & & & 58.46 & 0.000 \\
\hline Protective & 1 & $1.3 \%$ & 76 & $98.7 \%$ & 77 & $100 \%$ & & \\
\hline
\end{tabular}




\begin{tabular}{lllllll}
\hline Total & 11 & $11 \%$ & 89 & $89 \%$ & 100 & $100 \%$ \\
\hline
\end{tabular}

Table 2 shows that the relationship between respondents' perceptions of Figure 1 and the intention to stop smoking obtained a value of $p$ $=0.000(\mathrm{p}<0.05)$, which means a significant relationship between Figure 1 and the intention to stop smoking. From the analysis results, the value of $\mathrm{OR}=0.267$, which means that respondents who have an effective perception of Figure 1 have a 0.26 times chance of influencing the high intention to stop smoking compared to ineffective images.

Table 3. The relationship between perceptions of Figure 2

\begin{tabular}{|c|c|c|c|c|c|c|c|c|}
\hline \multirow{3}{*}{$\begin{array}{l}\text { Image } \\
\text { Perception } \\
2\end{array}$} & \multicolumn{4}{|c|}{ Intention to Quit Smoking } & \multirow{2}{*}{\multicolumn{2}{|c|}{ Total }} & \multirow{3}{*}{$\begin{array}{l}\text { OR } \\
(95 \% \\
\text { CI) } \\
\end{array}$} & \multirow{3}{*}{ P-value } \\
\hline & \multicolumn{2}{|c|}{ Low } & \multicolumn{2}{|c|}{ Tall } & & & & \\
\hline & $\mathbf{F}$ & $\%$ & $\mathbf{F}$ & $\%$ & $\mathbf{F}$ & $\%$ & & \\
\hline Not & 10 & $43.5 \%$ & 13 & $56.5 \%$ & 23 & $100 \%$ & \multirow{3}{*}{58.46} & \multirow{3}{*}{0.000} \\
\hline $\begin{array}{l}\text { Protective } \\
\text { Protective }\end{array}$ & 1 & $1.3 \%$ & 76 & $98.7 \%$ & 77 & $100 \%$ & & \\
\hline Total & 11 & $11 \%$ & 89 & $89 \%$ & 100 & $100 \%$ & & \\
\hline
\end{tabular}

Table 3 shows that the relationship between respondents' perceptions of Figure 2 and the intention to stop smoking obtained $\mathrm{p}$-value $=$ 0.000 ( $\mathrm{p}<0.05)$, which means a significant relationship between perceptions of Figure 2 and the intention to quit smoking. From the analysis results, the OR value $=58.46$, which means that respondents who have an effective perception of Figure 2 have a 58.46 times chance of influencing the high intention to stop smoking compared to ineffective images.

Table 4. The relationship between the perception of Figure 3 and the intention to stop smoking

\begin{tabular}{|c|c|c|c|c|c|c|c|c|}
\hline \multirow{3}{*}{$\begin{array}{c}\text { Image } \\
\text { Perception } \\
\mathbf{3}\end{array}$} & \multicolumn{4}{|c|}{ Intention to Quit Smoking } & \multirow{2}{*}{\multicolumn{2}{|c|}{ Total }} & \multirow{3}{*}{$\begin{array}{c}\text { OR } \\
(95 \% \\
\text { CI })\end{array}$} & \multirow{3}{*}{ P-value } \\
\hline & \multicolumn{2}{|c|}{ Low } & \multicolumn{2}{|c|}{ Tall } & & & & \\
\hline & $\mathbf{F}$ & $\%$ & $\mathbf{F}$ & $\%$ & $\mathbf{F}$ & $\%$ & & \\
\hline Not & 8 & $47 . \%$ & 9 & $52.9 \%$ & 17 & $100 \%$ & \multirow{4}{*}{23,704} & \multirow{4}{*}{0.000} \\
\hline Protective & & & & & & & & \\
\hline Protective & 3 & $3.6 \%$ & 80 & $96.4 \%$ & 83 & $100 \%$ & & \\
\hline Total & 11 & $11 \%$ & 89 & $89 \%$ & 100 & $100 \%$ & & \\
\hline
\end{tabular}

Table 4 shows that the relationship between respondents' perceptions of Figure 3 and the intention to stop smoking obtained $\mathrm{p}$-value $=$ 0.000 ( $\mathrm{p}<0.05)$, which means a significant relationship between perceptions of Figure 3 and the intention to quit smoking. From the analysis results obtained, $\mathrm{OR}=23.70$, which means that respondents who have an effective perception of Figure 3 have a 23,704 times chance of influencing the high intention to stop smoking compared to an ineffective image.

Table 5. The relationship between the perception of Figure 4 and the intention to stop smoking

\begin{tabular}{|c|c|c|c|c|c|c|c|c|}
\hline \multirow{3}{*}{$\begin{array}{l}\text { Image } \\
\text { Perception } \\
4\end{array}$} & \multicolumn{4}{|c|}{ Intention to Quit Smoking } & \multirow{2}{*}{\multicolumn{2}{|c|}{ Total }} & \multirow{3}{*}{$\begin{array}{l}\text { OR }(95 \% \\
\text { CI) }\end{array}$} & \multirow{3}{*}{ P-value } \\
\hline & \multicolumn{2}{|c|}{ Low } & \multicolumn{2}{|c|}{ Tall } & & & & \\
\hline & $\mathbf{F}$ & $\%$ & $\mathbf{F}$ & $\%$ & $\mathbf{F}$ & $\%$ & & \\
\hline $\begin{array}{l}\text { Not } \\
\text { Protective }\end{array}$ & 9 & $60 \%$ & 6 & $40 \%$ & 15 & $100 \%$ & 43,279 & 0.000 \\
\hline
\end{tabular}




\begin{tabular}{lllllll}
\hline Protective & 2 & $2.4 \%$ & 83 & $97.6 \%$ & 85 & $100 \%$ \\
\hline Total & 11 & $11 \%$ & 89 & $89 \%$ & 100 & $100 \%$ \\
\hline
\end{tabular}

Table 5 shows that the relationship between respondents' perceptions of Figure 4 and the intention to stop smoking obtained a value of $p$ $=0.000(\mathrm{p}<0.05)$, which means a significant relationship between perceptions of Figure 4 and the intention to quit smoking. From the analysis results, the value of $\mathrm{OR}=43,279$, which means that respondents who have an effective perception of Figure 4 have a 43,279 chance of influencing the high intention to quit smoking compared to an ineffective image.

Table 6. The relationship between the perception of Figure 5 and the intention to stop smoking

\begin{tabular}{|c|c|c|c|c|c|c|c|c|}
\hline \multirow{3}{*}{$\begin{array}{c}\text { Image } \\
\text { Perception } \\
5 \\
\end{array}$} & \multicolumn{4}{|c|}{ Intention to Quit Smoking } & \multirow{2}{*}{\multicolumn{2}{|c|}{ Total }} & \multirow{3}{*}{$\begin{array}{c}\text { OR }(95 \% \\
\text { CI })\end{array}$} & \multirow{3}{*}{ P-value } \\
\hline & \multicolumn{2}{|c|}{ Low } & \multicolumn{2}{|c|}{ Tall } & & & & \\
\hline & $\mathbf{F}$ & $\%$ & $\mathbf{F}$ & $\%$ & $\mathbf{F}$ & $\%$ & & \\
\hline Not & 10 & $27 \%$ & 27 & $73 \%$ & 37 & $100 \%$ & \multirow{4}{*}{22,963} & \multirow{4}{*}{0.00} \\
\hline Protective & & & & & & & & \\
\hline Protective & 1 & $1.6 \%$ & 62 & $98.4 \%$ & 63 & $100 \%$ & & \\
\hline Total & 11 & $11 \%$ & 89 & $89 \%$ & 100 & $100 \%$ & & \\
\hline
\end{tabular}

Table 6 shows the relationship between respondents' perceptions of Figure 5 and the intention to stop smoking; the value of $p=0.000$ $(\mathrm{p}<0.05)$ means a significant relationship between perceptions of Figure 5 and the intention to stop smoking. From the analysis results, the OR value $=22,963$, which means that respondents who have an effective perception of Figure 5 have a 22,963 chance of influencing the high intention to stop smoking compared to an ineffective image.

Table 7. Relationship between knowledge and intention to quit smoking

\begin{tabular}{|c|c|c|c|c|c|c|c|c|}
\hline \multirow{3}{*}{ Knowledge } & \multicolumn{4}{|c|}{ Intention to Quit Smoking } & \multirow{2}{*}{\multicolumn{2}{|c|}{ Total }} & \multirow{3}{*}{$\begin{array}{c}\text { OR } \\
(95 \% \\
\text { CI }) \\
\end{array}$} & \multirow{3}{*}{$\begin{array}{c}\text { P- } \\
\text { value }\end{array}$} \\
\hline & \multicolumn{2}{|c|}{ Low } & \multicolumn{2}{|c|}{ Tall } & & & & \\
\hline & $\mathbf{F}$ & $\%$ & $\mathbf{F}$ & $\%$ & $\mathbf{F}$ & $\%$ & & \\
\hline $\mathrm{Bad}$ & 9 & $64.3 \%$ & 5 & $35.7 \%$ & 14 & $100 \%$ & & \\
\hline Well & 2 & $2.3 \%$ & 84 & $97.7 \%$ & 86 & $100 \%$ & 75.6 & 0.000 \\
\hline Total & 11 & $11 \%$ & 89 & $89 \%$ & 100 & $100 \%$ & & \\
\hline
\end{tabular}

Table 7 shows that the relationship between knowledge and the intention to quit smoking obtained $\mathrm{p}$-value $=0.000(\mathrm{p}<0.05)$, which means a significant relationship between knowledge and the intention to stop smoking.
The analysis results obtained $\mathrm{OR}=75.6$, which means that respondents who have good knowledge have a 75.6 times chance of influencing the high intention to quit smoking than those with poor knowledge.

Table 8. The relationship between the environment and the intention to quit smoking

\begin{tabular}{|c|c|c|c|c|c|c|c|c|}
\hline \multirow{3}{*}{ Environment } & \multicolumn{4}{|c|}{ Intention to Quit Smoking } & \multirow{2}{*}{\multicolumn{2}{|c|}{ Total }} & \multirow{3}{*}{$\begin{array}{c}\text { OR } \\
(95 \% \\
\text { CI) }\end{array}$} & \multirow{3}{*}{ P-value } \\
\hline & \multicolumn{2}{|c|}{ Low } & \multicolumn{2}{|c|}{ Tall } & & & & \\
\hline & $\mathbf{F}$ & $\%$ & $\mathbf{F}$ & $\%$ & $\mathbf{F}$ & $\%$ & & \\
\hline Do not smoke & 2 & $61 \%$ & 31 & $93.9 \%$ & 33 & $100 \%$ & \multirow{3}{*}{0.416} & \multirow{3}{*}{0.268} \\
\hline Smoke & 9 & $13.4 \%$ & 58 & $86.6 \%$ & 67 & $100 \%$ & & \\
\hline Total & 11 & $11 \%$ & 89 & $89 \%$ & 100 & $100 \%$ & & \\
\hline
\end{tabular}

Table 8 shows that the relationship between the environment and the intention to quit smoking obtained $\mathrm{p}$-value $=0.268(\mathrm{p}>0.05)$, which means an insignificant relationship 
between the environment and the intention to quit smoking. From the analysis results, the value of $\mathrm{OR}=0.416$, which means that respondents who have a non-smoking environment have a 0.416 times chance of influencing the high intention to quit smoking compared to those who have a smoking environment.

Table 9 Relationship between behavior and intention to quit smoking

\begin{tabular}{|c|c|c|c|c|c|c|c|c|}
\hline \multirow{3}{*}{ Behavior } & \multicolumn{4}{|c|}{ Intention to Quit Smoking } & \multirow{2}{*}{\multicolumn{2}{|c|}{ Total }} & \multirow{3}{*}{$\begin{array}{c}\text { OR } \\
(95 \% \\
\text { CI) }\end{array}$} & \multirow{3}{*}{ P-value } \\
\hline & \multicolumn{2}{|c|}{ Low } & \multicolumn{2}{|c|}{ Tall } & & & & \\
\hline & $\mathbf{F}$ & $\%$ & $\mathbf{F}$ & $\%$ & $\mathbf{F}$ & $\%$ & & \\
\hline $\mathrm{Bad}$ & 7 & $9.5 \%$ & 67 & $90.5 \%$ & 74 & $100 \%$ & \multirow{3}{*}{0.575} & \multirow{3}{*}{0.406} \\
\hline Well & 4 & $15.4 \%$ & 22 & $84.6 \%$ & 26 & $100 \%$ & & \\
\hline Total & 11 & $11 \%$ & 89 & $89 \%$ & 100 & $100 \%$ & & \\
\hline
\end{tabular}

Based on table 4.25. shows that the relationship between behavior and the intention to stop smoking obtained $\mathrm{p}$-value $=0.406(\mathrm{p}>$ 0.05), which means an insignificant relationship between behavior and the intention to stop smoking. From the analysis results obtained OR $=0.575$, respondents who have good behavior have 0.575 times the opportunity to influence the high intention to stop smoking compared to those who have bad behavior.

Table 10. The relationship between perceptions of PKB and the intention to stop smoking

\begin{tabular}{|c|c|c|c|c|c|c|c|c|}
\hline \multirow{3}{*}{ Perception } & \multicolumn{4}{|c|}{ Intention to Quit Smoking } & \multirow{2}{*}{\multicolumn{2}{|c|}{ Total }} & \multirow{3}{*}{$\begin{array}{c}\text { OR } \\
(95 \% \\
\text { CI }) \\
\end{array}$} & \multirow{3}{*}{$P$ value } \\
\hline & \multicolumn{2}{|c|}{ Low } & \multicolumn{2}{|c|}{ Tall } & & & & \\
\hline & $\mathbf{F}$ & $\%$ & $\mathbf{F}$ & $\%$ & $\mathbf{F}$ & $\%$ & & \\
\hline $\mathrm{Bad}$ & 10 & $83.3 \%$ & 2 & $16.7 \%$ & 12 & $100 \%$ & \multirow{3}{*}{43.5} & \multirow{3}{*}{0.000} \\
\hline Well & 1 & $1.1 \%$ & 87 & $98.9 \%$ & 88 & $100 \%$ & & \\
\hline Total & 11 & $11 \%$ & 89 & $89 \%$ & 100 & $100 \%$ & & \\
\hline
\end{tabular}

Table 10 shows that the relationship between perceptions of PKB to stop smoking obtained $p$ value $=0.000(\mathrm{p}<0.05)$, which means that there is a significant relationship between perceptions of PKB and the intention to stop smoking. From the analysis results, it was obtained that the OR $=43.5$, which means that respondents who have a good perception of PKB have a 43.5 times chance of influencing the high intention to stop smoking compared to those who have a bad perception of PKB.

\section{DISCUSSION}

The Relationship Between Perception of Images and Respondents' Intention to Quit Smoking

a. The relationship between the perception of Figure 1 and the respondent's intention to quit smoking

Based on the results of the kai-squared test, the value of $p=0.000(p<0.05)$ and which means that there is a significant relationship between respondents' perceptions of Figure 1 (the picture with oral cancer) and the respondent's intention to stop smoking. The relationship between the respondent's perception of Figure 1 and the intention to stop smoking obtained a value of $p=0.000(p<0.05)$, which means a significant relationship between Figure 1 and the intention to stop smoking. From the analysis results, the value of OR = 0.267 , which means that respondents who have an effective perception of Figure 1 have a 0.26 times chance of influencing the high intention to quit smoking compared to ineffective images.

From the study results, 85 percent of respondents who have a protective perception of Figure 1 have a high intention to quit smoking, while 11 percent of respondents who have a non-protective perception of Figure 1 have a low intention to quit smoking.

b. The relationship between perceptions of Figure 2 and the respondents' intention to quit smoking.

The results of the kai squared test showed the value of $p=0.0001(p<0.05)$. These results indicate that there is a significant relationship between Figure 2 (picture of smoking people with smoke resembling a skull) and the 
respondent's intention to stop smoking, from the analysis results obtained OR $=58.46$, which means that respondents who have an effective perception of Figure 2 have a 58 chance, 46 times the higher the intention to quit smoking than the ineffective image.

From the study results, 76 percent of respondents who said they were protective of Figure 2 had a high intention to quit smoking, and 10 percent of respondents who were not protective of Figure 2 had a low intention of quitting smoking.

Of all the pictures, picture 2 (picture of a smoking person with skull smoke) has the lowest score, an average score of 5.10. Respondents thought this image was less scary and paid less attention to the health hazards of smoking.

c. The relationship between the perception of Figure 3 with the respondent's intention to quit smoking.

Based on the results of the kai-squared test, the value of $p=0.000(p<0.05)$ means that there is a significant relationship between respondents' perceptions of Figure 3 (lung cancer picture) on cigarette packaging and respondents' intention to stop smoking. From the analysis results obtained, $\mathrm{OR}=23.70$, which means that respondents who have an effective perception of Figure 3 have a 23,704 times chance of influencing the high intention to stop smoking compared to an ineffective image.

From the study results, 80 percent of respondents who are protective of Figure 3 have a high intention to quit smoking, while 8 percent of respondents who are not protective of Figure 3 have a low intention to quit smoking.

d. The relationship between the perception of Figure 4 with the respondent's intention to quit smoking.

Based on the results of the kai-squared test, the value of $p=0.001(p<0.05)$ means that there is a strong relationship between the respondent's perception of Figure 4 (lung cancer picture) and the respondent's intention to quit smoking. From the analysis results, the value of $\mathrm{OR}=43,279$, which means that respondents who have an effective perception of Figure 4 have a 43,279 chance of influencing the high intention to quit smoking compared to an ineffective image.
From the study results, 83 percent of respondents who have a protective perception of Figure 4 also have a high intention to quit smoking, while 9 percent of respondents who are not protective of Figure 4 have a low intention to quit smoking.

e. The relationship between the perception of Figure 5 with the respondent's intention to quit smoking

Based on the results of the kai-squared test, the value of $p=0.000(p<0.05)$ means that there is a significant relationship between the respondent's perception and Figure 5 (picture of a smoking person with smoke billowing and a small child nearby) on the intention to stop smoking. In Figure 5, 63\% of respondents consider the protective image while (37\%) consider it unprotected. From the analysis results, the $\mathrm{OR}$ value $=22,963$, which means that respondents who have an effective perception of Figure 5 have a 22,963 times chance of influencing the high intention to stop smoking compared to an ineffective image.

From the study results, 62 percent of respondents who have a protective attitude towards Figure 5 will also have a high intention to quit smoking, while 10 percent of respondents who have an unprotected attitude towards Figure 5 will also have a low intention to quit smoking.

Figure 5 is a warning image of the dangers of cigarette smoke; namely, smoking harms children (illustration of a father holding a child while smoking. Giving a warning picture of the dangers of smoking on cigarette packs is expected to discourage smokers and finally stop smoking. If not, at least the government can socialize the dangers of smoking precisely and accurately.

According to respondents, figure 5 is the least scary image, with the lowest average score of 5.89. Based on the interview results, the effect of the picture is not understood by the respondents. This study aligns with Choiri's research (2015), which concluded that people choose picture 5 when they want to buy cigarettes because it is not too scary.

f. Relationship Between Knowledge and Intention to Stop Smoking Respondents 
Based on the results of the kai-squared test, the value of $p=0.000(p<0.05)$ means that there is a significant relationship between knowledge and the intention to quit smoking. The analysis results obtained $\mathrm{OR}=75.6$, which means that respondents who have good knowledge have a 75.6 times chance of influencing the high intention to quit smoking than those with poor knowledge.

From the study results, 84 percent of respondents who have good knowledge will have a high intention to quit smoking, while 9 percent of respondents who have poor knowledge will have poor intentions to quit smoking.

Based on the multivariate test results, knowledge has not significantly affected the intention to stop smoking. Some respondents revealed that respondents already knew the dangers and diseases caused by smoking, but according to respondents, this was only a theory that was not necessarily true. Some respondents also revealed that he smokes and does not get diseases like what is listed on the cigarette packaging.

g. The relationship between the environment and the respondent's intention to quit smoking

Based on the kai squared test results, the value of $p=0.268(\mathrm{p}>0.05)$ means no significant relationship between the environment and the intention to quit smoking. From the analysis results, the value of OR = 0.416 , which means that respondents who have a non-smoking environment have a 0.416 times chance of influencing the high intention to quit smoking compared to those who have a smoking environment.

From the study results, 58 percent of respondents who have a good environment will have a high intention to quit smoking, while 2 percent of respondents who have a bad environment will have a bad intention to quit smoking.

h. The relationship between behavior and the respondent's intention to quit smoking

Based on the kai squared test results, the value of $p=0.406(p>0.05)$ means no significant relationship between behavior and the intention to quit smoking. From the analysis results, the OR value $=0.575$, which means that respondents who have good behavior have a 0.416 times chance of influencing the high intention to stop smoking compared to those who have bad behavior.

From the study results, 84.6 percent of respondents who have good behavior will have a high intention to quit smoking, while 9.5 percent of respondents who have bad behavior will have a bad intention to quit smoking.

Based on the research results with interviews, addiction and a sense of eagerness to smoke inhibit reducing the intention to stop smoking. Other reasons are not being afraid of warnings or not being indifferent to the situation. Also, the smokers feeling comfortable and feeling good that has been felt from cigarettes. They state that stress can only be eliminated by smoking. The conditions and a supportive environment because there are still many who sell cigarettes freely and have not felt the negative effects of smoking are other reasons that prevent respondents from reducing their intention to quit smoking.

i. The relationship between the perception of PKB with the respondent's intention to quit smoking

Based on the results of the kai-squared test, the value of $p=0.000(p<0.05)$ means that there is a significant relationship between the perception of PKB and the intention to stop smoking. Odd Ratio Perception of pictorial health warnings on students' smoking intentions in the bivariate analysis is 435 , so it can be said that the impact on students who have a good perception of $\mathrm{PKB}$ is very high in their intention to quit smoking.

From the study results, 87 percent of respondents who have a good perception of PKB will have a high intention to quit smoking, while 10 percent of respondents who have a bad perception of PKB will have a bad intention to quit smoking.

Of the five images of the first round of health messages, images with scary concepts are protective of increasing smoking cessation intentions, where images that are considered scary (Figure 1 oral cancer, Figure 3 throat cancer, and Figure 4 lung cancer) tend to be avoided by teenagers when buying cigarette. See Picture 2 (picture of the smoking person 
with skull smoke) and picture 5 (image of smoking person and small child).

Based on the results of interviews, respondents' perceptions of the existence of the image are to warn people to reduce smoking because the impact is not good. Some respondents stated that it is a warning, appeal, notification not to smoke because the consequences are quite dire, so the number of smokers is reduced. Respondents agree that smoking can result in death and serious illness. In addition, the design of the PKB image on cigarette packs was considered by the respondents to be quite good and attractive, causing fear and a deterrent effect for those who saw it, thus encouraging them to reduce and stop smoking.

\section{CONCLUSION}

1. Most of the respondents considered that pictorial health messages on cigarette packaging prevented students from quitting smoking.

2. Based on the study results, picture 3 (throat cancer) became the most frightening image for respondents of the five images of health messages. Furthermore, picture 4 (lung cancer) and picture 1 (mouth cancer) are the next scary pictures, while picture 2 (pictures of smoking people with skull smoke) and picture 5 (pictures of smoking people and small children) are the least scary pictures according to respondents.

3. Based on the interview results, the effect of the image is spooky, quite scary, and encouraging to stop smoking, scary and starting to reduce cigarette consumption, but some say that it was scary, terrible, or disgusting at first, but after a long time it became normal.

\section{REFERENCES}

Aditama, Tjandra Yoga. 1997. Rokok dan kesehatan. UI Press Jakarta.

Albery, Ian P. \& Mufano, Marcus. 2011. Psikologi Kesehatan, Panduan Lengkap dan Komprehensif Bagi Studi Psikologi Kesehatan. Mitra Setia.

Annisa Dwi Rahmawati, Andi. 2015. Persepsi Remaja Terhadap Kemasan Menakutkan pada Peringatan Kesehatan Bergambar di Bungkus Rokok Ditinjau dari Extended Parallel Process Model. Skripsi FKM UI. Depok
4. According to the results of the study, in general, the images on cigarette packaging are trustworthy, unpleasant, and terrible, while the respondents' perceptions which are quite low, about the images on the packaging, are

5. prevent teens from smoking, although viewing these images does not invalidate the urge to smoke, and the images can make smokers want to quit smoking.

6. The relationship between knowledge and the intention to quit smoking is significant. The relationship between perceptions of the PKB image and the intention to quit smoking is significant, but the relationship between environment and behavior is not significant.

7. Multivariate analysis showed that simultaneously there was no independent variable that had a significant effect on quitting smoking.

8. Based on the results of research with interviews, addiction and a sense of eagerness to smoke inhibits reducing the intention to stop smoking; other reasons are not being afraid of warnings, not being indifferent to the situation, feeling comfortable and feeling good that has been felt from cigarettes, stress that can only be eliminated by smoking, conditions and a

9. supportive environment because many who sell cigarettes freely and have not felt the negative effects of smoking are other reasons that prevent respondents from reducing their intention to quit smoking.

Aqidah Rahmawati. 2016. Hubungan Perceived Risk dan Intensi Berhenti Merokok Pada Mahasiswa. Ejounal UNNES

Arikunto, Suharsimi. 2012. Prosedur Penelitian Suatu Pendekatan Praktek. Jakarta : Rineka Cipta.

Aula, Lisa Elizabeth. 2010. Stop Merokok! Sekarang Atau Tidak Sama Sekali. Bandung : Garailmu.

Basyir, Abu Umar. 2006. Mengapa Ragu Tinggalkan Rokok?. Pustaka At-Tazkia. Jakarta. 
Cooper, Donald R., dan Emory, C. William. 1996. Bussines Research Methods. Jakarta: Erlangga.

Ilham, D. (2019). Implementing Local Wisdom Values in Bride and Groom Course at KUA Bara SubDistrict, Palopo City. Jurnal Konsepsi, 8(1), 1-9.

Ilham, D. (2020). The Challenge of Islamic Education and How to Change. International Journal of Asian Education, 1(1), 09-20.

Ilham, D. (2020). Persoalan-Persoalan Pendidikan dalam Kajian Filsafat Pendidikan Islam. Didaktika: Jurnal Kependidikan, 9(2), 179188.

Efendi, Mohammad. 2005. Penggunaan Cognitive Behavior Therapy Untuk Mengendalikan Kebiasaan Merokok di Kalangan Siswa melalui Peningkatan Perceived Self Efficacy Berhenti Merokok. Jurnal Pendidikan dan Kebudayaan No. 056, Tahun ke-11, September 2005. (www.isjd.pdii.lipi.go.id)

Firman, F., Aswar, N., Sukmawaty, S., Mirnawati, M., \& Sukirman, S. (2020). Application of the Two Stay Two Stray Learning Model in Improving Indonesian Language Learning Outcomes in Elementary Schools. Jurnal Studi Guru Dan Pembelajaran, 3(3), 551-558.

Firman, F., Mirnawati, M., Usman, U., \& Syamhari, S. (2019). How to Apply the Process Skills Approach to Improving Indonesian Language Learning Outcomes in Senior High Schools. Didaktika: Jurnal Kependidikan, 8(3), 145154.

Firman, F., Mirnawati, M., Sukirman, S., \& Aswar, N. (2020). The Relationship Between Student Learning Types and Indonesian Language Learning Achievement in FTIK IAIN Palopo Students. Jurnal Konsepsi, 9(1), 1-12.1

Friedenberg, Lisa. 1995. Psychological Testing: Design, Analysis, and Use. Boston. Guilford.

Hammond, David, et al. 1. 2012. Perceived effectiveness of pictorial health warnings among Mexican youth and adults: a population-level intervention with the potential to reduce tobacco-related inequities. Cancer Causes ControlDOI 10.1007/s10552-0129902-4

Hasan, M Iqbal. 2003. Pokok-pokok Materi Statistik 1 Edisi Kedua. Bumi Aksara. Jakarta

Hastono, Sutanto. 2007. Analisa Data Kesehatan. Universitas Indonesia. Jakarta.

Hidayat, A.A. 2005. Pengantar Ilmu Keperawatan Anak 1: Buku 1. Salemba Medika. Jakarta.

Husaini, Aiman. 2006. Tobat Merokok : Rahasia \& Cara Empatik Berhenti Merokok. Pustaka liman. Depok.
Jaya, M. 2009. Pembunuh Berbahaya Itu Bernama Rokok. Riz'ma. Yogyakarta.

Kaso, N., Subhan, S., Ilham, D., \& Aswar, N. (2021). Penguatan Mitigasi Radikalisme Melalui Pembelajaran Berbasis Kearifan Lokal pada Taman Kanak-Kanak di Kota Palopo. Madaniya, 2(2), 152-167.

Kaso, N., Mariani, M., Ilham, D., Firman, F., Aswar, N., \& Iksan, M. (2021). The Principal's Leadership: How to Improve the Quality of Teaching and Learning Process in State Junior High School of Luwu. Jurnal Ad'ministrare, $8(1), 49-58$.

Kaso, N., Nurjihad, A., Ilham, D., \& Aswar, N. (2021). Facebook and its Impact on Students' Learning Achievement at State Islamic High School of Palopo. Jurnal Studi Guru dan Pembelajaran, 4(1), 1-15.

Kaso, N., Aswar, N., Firman, F., \& Ilham, D. (2019). The Relationship between Principal Leadership and Teacher Performance with Student Characteristics Based on Local Culture in Senior High Schools. Kontigensi: Jurnal Ilmiah Manajemen, 7(2), 87-98.

Kesowo, Bambang. 2003. UU RI No. 20 Tahun 2003 Tentang Sistem Pendidikan Nasional. Jakarta : Eka Jaya

Maharani, Eka Pratiwi. 2007. Faktor-Faktor Resiko Osteoporosis Lutut. Tesis Program Studi Magister Epidemologi Program Pascasarjana Universitas Diponegoro.

Moleong, L. 2014. Metode Penelitian Kualitatif. Edisi Revisi. PT. Remaja Rosdakarya. Bandung

Muh. Amin S. 2016. Hubungan Peringatan Kesehatan Bergambar terhadap intensi berhenti merokok siswa SMA di Makasar. Tesis Fakultas Ilmu Kesehatan Masyarakat UI.

Notoadmodjo, S. 2003. Pendidikan dan prilaku kesehatan. PT. Rineka Cipta. Jakarta

Nurjaya, N., Affandi, A., Ilham, D., Jasmani, J., \& Sunarsi, D. (2021). Pengaruh Kompetensi Sumber Daya Manusia Dan Kemampuan Pemanfaatan Teknologi Terhadap Kinerja Aparatur Desa Pada Kantor Kepala Desa Di Kabupaten Gunungkidul, Yogyakarta. JENIUS (Jurnal Ilmiah Manajemen Sumber Daya Manusia), 4(3), 332-346.

Peraturan Pemerintah Nomor. 109 Tahun 2012 tentang Pengamanan Bahan yang Mengandung Zat Adiktif

Potter \& Perry. 2009. Fundamental Keperawatan Edisi 7. Salemba Medika. Jakarta

Setiawan E. Kamus Besar Bahasa Indonesia. [Online] ; 2014. http:/kbbi.web.id/pustaka.

Smet, Bart. 1994. Psikologi Kesehatan. PT. Gramedia Widiasarana Indonesia. "Pengantar" 
dalam Calvin S. Hall dan Gardner Lindzey, Teori-teori holistik (OrganismikFenomenologis), Penerjemah Yustinus, Kanisius. Jakarta.

Smet, Bart. 1994. Psikologi Kesehatan. PT. Gramedia Widiasarana Indonesia. "Pengantar" dalam Calvin S. Hall dan Gardner Lindzey,Teori-teori holistik (OrganismikFenomenologis), Penerjemah Yustinus, Kanisius. Jakarta.

Stephani Raihana Hamdan. 2015. Pengaruh Peringatan Bahaya Rokok Bergambar pada Intensi Berhenti Merokok. Jurnal Mimbar Vol. 31 No. 1.
Sugiyono. 2001. Metode Penelitian. Alfabeta. Bandung.

Sugiyono. 2009. Metode Penelitian Kuantitatif, Kualitatif dan R\&D. Bandung : Alfabeta.

Sugiyono. 2012. Memahami Metode Penelitian Kuantitatif. Afabeta. Bandung.

Sweeting, R.L. 1990. A Value Approach to Health Behaviour. Human Kinetik Books. Illinois

Tobacco atlas. 2012. Cigarette Consumption - top 5 Cigarette Consuming Countries. United States: Tobacco Atlas.

Wong, D, dkk. 2009. Buku Ajar Keperawatan Pediatrik Vol 1. EGC : Jakarta 